\title{
PLURALISM DISCOURSE The Views of Young Muhammadiyah Intellectuals
}

\author{
Biyanto \\ IAIN Sunan Ampel Surabaya, Indonesia
}

\begin{abstract}
This article discusses the issue of religious pluralism in the perspective of young Muhammadiyah intellectuals. It aims at understanding the social construction and configuration of this issue. It uses as an approach the sociology of knowledge, emphasising the interrelatedness of the product of thought and social background. It argues that the understanding of religious pluralism of young Muhammadiyah intellectuals varies. Those who accept religious pluralism and those who reject it have different understandings on this concept. Some embrace religious pluralism because of social, political, anthropological, philosophical, and theological perspectives. For them, pluralism is different from plurality, tolerance, and relativism. Those who reject religious pluralism perceive the idea of pluralism from philosophical and theological perspectives. In this sense, pluralism is understood as relativism. Their different views and attitudes are due to their different social construction namely education, social interaction, and the genealogy of knowledge.
\end{abstract}

Keywords: Religious pluralism, relativism, young Muhammadiyah intellectuals, intellectual dynamics.

\section{Introduction}

Muhammadiyah, one of the largest socio-religious organizations in Indonesia, has shown various responses towards pluralism. Some of Muhammadiyah's most prominent figures appear to appreciate the idea while others do otherwise. Among the first group are senior prominent personalities such as Ahmad Syafii Ma'arif (born in 1935), Amin 
Abdullah (born in 1953), Abdul Munir Mulkhan (born in 1946), and Muslim Abdurrahaman (born in 1947). In the second group, there are some others, including Muhammad Muqoddas (born in 1956), Yunahar Ilyas, and Mustafa Kamal Pasha (born in 1939). According to the latter specifically, the idea of pluralism is contradictory to Islamic teaching. This discourse has caused a lot of confusion among members of Muhammadiyah. ${ }^{1}$

Actually, the attitudes of young Muhammadiyah intellectuals regarding pluralism are also diverse. Some of them agree with pluralism, while others disagree. Young figures in Muhammadiyah such as Zuly Qodir (born in 1971), Syamsul Arifin (born in 1966), Zakiyuddin Baidhawy (born in 1972), Ahmad Najib Burhani (born in 1976), Sukidi (born in 1976), Muhammad Shofan (born in 1975), Pradana Boy ZTF (born in 1977), Yayah Khisbiyah (born in 1968) and Dewi Candraningrum (born in 1971) generally accept the idea. In one of his papers Zuly Qodir, for example, states that pluralism is inevitable, as it is part of natural law (that is, the sunnat Allals. ${ }^{2}$ Meanwhile, Syamsul Arifin suggests that rejecting pluralism may incite violence. For him, therefore, Muhammadiyah is required to promote pluralist Islam so that a form of moderate Islam may prevail. ${ }^{3}$

However, other young Muhammadiyah intellectuals take an opposition stance towards pluralism. Among this group are Adian Husaini (born in 1965), Fatkhurrazi Reno Sutan (born in 1966), Mashud (born in 1968), Syamsul Hidayat (born in 1964), Andri Kurniawan (born in 1968), and Ahmad Khoirul Fata (born in 1981). Adian Husaini is very consistent in rejecting not only pluralism but also secularism and liberalism. He regards these three notions as

\footnotetext{
1 Yunahar Ilyas, "Pluralisme Agama dalam Perspektif Islam," in Syamsul Hidayat and Sudarno Shobron (eds.), Pemikiran Mubammadiyab: Respon terbadap Liberalisasi Islam (Surakarta: Muhammadiyah University Press, 2005), pp. 283-296; See also, Mustafa Kamal Pasha, "Wacana Pluralisme dan Liberalisasi Agama: Keresahan Warga Muhammadiyah," in Hidayat and Shobron (eds.), Pemikiran Mubammadiyah, pp. 339357.

2 Zuly Qodir, "Muhammadiyah dan Pluralisme Agama," in Imron Nasri (ed.), Pluralisme dan Liberalisme: Pergolakan Pemikiran Anak Muda Muhammadiyah (Yogyakarta: Citra Karsa Mandiri, 2005), pp. 87-93.

${ }^{3}$ Syamsul Arifin, "Jangan Biarkan Keberagaman Dicederai," Jawa Pos (3 Juni 2008), p 4.
} 
something alien to Islam and its noble teaching. ${ }^{4}$ That is why Reno Sutan believes that liberalism and pluralism are dangerous for Muhammadiyah. ${ }^{5} \mathrm{He}$ fears that progressive thoughts such as these may deconstruct the very basis of Muhammadiyah belief and turn its members away from the tenet of amar ma'ruf nahi munkar. ${ }^{6}$ In debates that have taken place in mailing lists, those who object to liberalism stigmatize the liberals as "not belonging to our group" or "laysa minna?

The differences in thought and attitude among young Muhammadiyah intellectuals are of a discursive nature. They therefore warrant analysis from a sociological perspective since a man's views and attitude are often closely related to his social construct. ${ }^{8}$ As Doyle McCarthy, for example, suggests that individuals and society tend to be shaped by their social construction. ${ }^{9}$ In this context, it is important to explore and analyze the social background which shapes the way of thinking of these young Muhammadiyah intellectuals. It is also important to trace back a possible correlation between their views and those of Muhammadiyah's first generation.

\section{The Context of the Discourse}

The rise of young Muhamadiyah intellectuals, both those who agree and those who disagree with pluralism, cannot be detached from the internal and external situation of Muhammadiyah as an organisation. What we mean by external condition here is the development of Islamic discourse in the Islamic world in general and

\footnotetext{
${ }^{4}$ Adian Husaini, Pluralisme Agama: Fatwa MUI yang Tegas dan tidak Kontroversial (Jakarta: Pustaka al-Kautsar, 2005), p. 7; Idem, Islam Liberal, Pluralisme Agama dan Diabolisme Intelektual (Surabaya: Risalah Gusti, 2005), p. 11.

${ }^{5}$ Fakhrurazi Reno Sutan, "Virus Liberal di Muhammadiyah," Tabligh, vol. 02, no. 08 (Maret 2004), pp. 14-15.

${ }^{6}$ Interview with Fakhrurazi Reno Sutan, Jakarta, 29 August 2007. Amar ma'ruf nabi munkar is an Islamic slogan meaning the encouragement to do good deeds and prevention from evil doings.

7 Anonym, "Laysa Minna: Mereka Bukan Golongan Kami (Jejak Liberalisme, Pluralisme, Inklusivisme di Muhammadiyah)," suaramuslim.net. 26 June 2004.

8 Peter L. Berger and Thomas Luckman, The Social Construction of Reality: A Treatise in the Sociology of Knowledge (England-USA: Penguin Books, 1991), p. 17.

9 E. Doyle McCarthy, Knowledge as Culture: The Sociology of Knowledge (New York: Routledge, 1996), p. 1.
} 
in Indonesia in particular, which can be classified, in general terms, into liberalism and fundamentalism. According to Kurzman, Muslims with a liberal ideology have gained in popularity since the 1970's, concurrent with the strengthening of the position of fundamentalist Muslim group. ${ }^{11}$ Ever since, both schools of thought have been involved in debates over contemporary issues in Islam.

The debate between liberal Islam and fundamentalist Islam in Indonesia becomes clearer with the emergence as an iconic figure of Nurcholish Madjid, also known as Cak Nur, (1939 - 2005). Even though he never use the term 'liberal Islam' in his ideas, if we look at all his ideas since 1970's, it is reasonable for liberal thinkers to place him as a pioneer of liberal Islam in Indonesia. Two of Madjid's writings that can be considered as promoters of a renewal in Islamic thought in Indonesia are "Keharusan Pembaruan Pemikiran Islam dan Masalah Integrasi Umat" (the urgency of the renewal of Islamic thought and integration problem within Islamic community) and "Menyegarkan Paham Keagamaan di Kalangan Umat Islam Indonesia" (Reviving religious views among Indonesian Muslim community). ${ }^{12}$ In sum, these two encouraged Muslims in Indonesia to make fundamental changes in order to keep up with social and political changes.

Madjid's thoughts and those of other likeminded intellectuals seemingly inspired young thinkers from both Nahdlatul Ulama (NU) and Muhammadiyah, the two largest Muslim organizations in Indonesia. Within NU, members of $\mathrm{JIL}^{13}$ also voiced several themes promoted by Madjid. In fact, JIL was also established in Paramadina,

\footnotetext{
11 Charles Kurzman, "Pengantar: Islam Liberal dan Konteks Islaminya," in Charles Kurzman (ed.), Wacana Islam Liberal: Pemikiran Islam Kontemporer tentang Isu-isu Global, transl. Bahrul Ulum (Jakarta: Paramadina, 2003), p. xxvii.

12 Nurcholish Madjid, Islam Kemodernan dan Keindonesiaan (Bandung: Mizan, 1992), pp. 204-214 and pp. 239-256.

13 Jaringan Islam Liberal (JIL) is an institution formed by young intellectuals within Nahdlatul Ulama circle led by Ulil Abshar Abdalla. JIL are actively engaged in many activities since March 2001. Since June the 25th 2001, JIL has hosted newspaper columns, internet website, and radio talkshow in spreading its ideas. See, for example Adian Husaini dan Nu'im Hidayat, Islam Liberal: Sejarah, Konsepsi, Penyimpangan, dan Jawabannya (Jakarta: Gema Insani Press, 2002), p. 4.
} 
an institution founded by Madjid. Some of the founders of JIL, not necessarily from an NU background, can be considered as Madjid's students/followers. Among them are Luthfi Assyaukanie, Hamid Basyaib, Ihsan Ali Fauzi, Saiful Mujani, Ahmad Sahal and Budhy Munawar Rahman. ${ }^{14}$ Meanwhile, within Muhammadiyah, a group of young thinkers also emerged, labeling themselves Jaringan Intelektual Muda Muhammadiyah (JIMM or Young Muhammadiyah Intellectuals Network). They also seemed very eager to participate in discourse about contemporary Islam. Liberal Islam groups and their ideas have undergone an impressive development through their publication in many forms, including books and opinions in the mass media.

The external conditions explained above have clearly shaped the rise of liberals and conservatives in Muhammadiyah. The group opposing liberalism within Muhammadiyah also exhibit external influences here; they mention that foreign parties have been involved in promoting the development of ideas proposed by the liberalist group. Adian Husaini, for example, suggests that, since the end of cold war, the West has viewed Islam as a threat. Islam has replaced Communism, which was seen as the main enemy of the West during the Cold War. Since then, Islam has been perceived as an enemy whose position and strength need to be weakened. In doing so, several projects, including the liberalization of Islam have, been thrust upon Indonesia and other parts of Islamic world. According to Husaini, this is all part of a Western strategy to impose its hegemony on the Islamic world. This strategy can be broken down into three streams: Christianization, imperialism and Orientalism. ${ }^{15}$ To support his argument, Husaini points to The Asia Foundation (TAF) as one foreign NGO that is very active in funding the campaign for religious liberalism and pluralism. In order to participate actively in spreading inclusive and pluralist values, TAF has also, since the 1970s, sponsored many activities by Muslim-based NGO's. Some of the themes proposed by TAF are civic education, human rights, conflict reconciliation, gender equity, and interfaith dialogue.

${ }^{14}$ Ahmad Gaus AF, "Islam Progresif: Wacana Pasca Arus Utama (Peta Pemikiran dan Gerakan Islam di Indonesia)," Tashwirul Afkar, 22 ${ }^{\text {th }}$ edition (2007), p. 108.

15 Adian Husaini, Liberalisasi Islam di Indonesia: Fakta dan Data (Jakarta: Dewan Dakwah Islamiyah Indonesia, 2007), p. 57. 
The considerable funding from the West to develop liberalism and pluralism has prompted criticism from those who oppose the ideas of liberal Islam. Anti-liberal groups have in fact never had access to foreign funding, even from Islamic countries in Middle East. According to Yunahar Ilyas, foreign donors so far are only interested in funding activities fostering liberalism and pluralism. To offset this, Yunahar has strongly encouraged more Muhammadiyah thinkers to struggle against secularism, liberalism and pluralism. ${ }^{16}$

Turning out attention to the internal condition of Muhammadiyah, that which has been going on within this organisation as far as discursive debates are concerned, in this area Muhammadiyah has come under severe criticism both from Indonesian observers and foreign academics for not allowing new discourse to flourish. One criticism was leveled at Muhammadiyah at the $41^{\text {st }}$ congress of the organization, held in Solo in late 1985. ${ }^{17}$ A book entitled Mubammadiyah dalam Kritik dan Komentar by Karim contained some cynical comments from several observers who questioned Muhammadiyah's existence as an organization dedicated to renewal. In this book, Muhammadiyah's tendency to be routinely involved in organizing fund-raising activities was also a major concern. In addition, the contributors questioned Muhammadiyah's commitment to developing the values of art and culture. $^{18}$

Criticism of Muhammadiyah continued at its $42^{\text {nd }}$ congress in Yogyakarta in 1990. Some attackss focused on its religious views concerning issues of particular importance at that time, its renewal mission, its role in education and economic empowerment projects, da'wah (propagation) and politics. ${ }^{19}$ On the other hand, some foreign observers also highlighted other issues. Howard M. Federspiel for

\footnotetext{
16 Inteview with Yunahar Ilyas, Probolinggo, 20 January 2008.

${ }^{17}$ For this account, refer to, Azyumardi Azra, "Muhammadiyah: A Preliminary Study," Studia Islamika, vol. 1, no. 2 (1994): pp. 187-200.

18 M. Rusli Karim (ed.), Muhammadiyah dalam Kritik dan Komentar (Jakarta: Rajawali Press, 1986).

${ }^{19}$ Usman Yatim dan Almisar Hamid (ed.), Mubammadiyah dalam Sorotan (Jakarta: Bina Rena Pariwara, 1993).
} 
example, labeled Muhammadiyah 'orthodox Islam'.20 Meanwhile, Nakamura considered Muhammadiyah an urban phenomenon. ${ }^{21}$

It is the criticism of Muhammadiyah's mission of renewal that has drawn most attention. This criticism has unveiled an interesting fact: Muhammadiyah's involvement in so many social action programs has in fact hampered its efforts to develop discourse useful for the wellbeing of both the ummah and the organization. This very situation has raised concerns among members of the organisation who expect Muhammadiyah to make an intellectual contribution to the whole tradition of Islam. ${ }^{22}$ Efforts to encourage Muhammadiyah's contribution in developing Islamic thoughts have been underway since 1995, when it had its 43 $3^{\text {rd }}$ congress in Banda Aceh. ${ }^{23}$ At that convention, Muhammadiyah's response, perhaps overdue, to criticisms by Asep Purnama Bahtiar and Nurwanto, was put forward. One of the responses was to change the name of Majlis Tarjib (which denotes only legal counselling) to Majlis Tarjih dan Pengembangan Pemikiran Islam (MTPPI, meaning, 'legal counselling and the development of Islamic thought.' This new name stressed the intellectual aspect of the organization. ${ }^{24}$ At its $45^{\text {th }}$ congress in Malang, MTTPI changed its name again to Majlis Tarjib dan Tajdid which means 'legal counselling and renewal'. This new name was chosen to stimulate more renewal efforts in Muhammadiyah. The word tajdi has hitherto been understood in Muhammadiyah simply as purification. That is why the

${ }^{20}$ Howard M. Federspiel, "Muhammadiyah Sebagai Gerakan Islam Ortodoks," in M. Din Syamsuddin (ed.), Mubammadiyah Kini dan Esok (Jakarta: Pustaka Panjimas, 1990), pp. 81-121.

21 Nakamura's statement is based on the success of Muhammadiyah in assimilating Islamic values with modern urban milieu. The success of Muhammadiyah is showed by its organizational growth and activities in education and other social institutions. Such growths are apparent in urban areas. He also compares between Muhammadiyah and Nahdlatul Ulama which is more welcomed in rural areas. See, Mitsuo Nakamura, "The Crescent Arises Over the Banyan Tree: A Study of Muhammadiyah in a Central Java" (Unpublished PhD Thesis, Cornel University, 1976), pp. 320-321.

22 Pimpinan Pusat Muhammadiyah, "Keputusan Muktamar ke-45 tentang Program Muhammadiyah 2005-2010," Berita Resmi Muhammadiyah, no. 01 (September 2005), p 46.

${ }^{23}$ Fathurrahman Djamil, "The Muhammadiyah and the Theory of Maqasid al-Syariah," Studia Islamika, vol. 2, no. 1 (1995): pp. 53-68.

24 Asep Purnama Bahtiar dan Nurwanto, "Wacana dan Agenda Reformasi Muhammadiyah," in Nasri (ed.), Pluralisme dan Liberalisme, pp. 46-47. 
renewal efforts that the organisation has undertaken were always about renewing ritual aspects of Islam rather than, say, its political, economic or intellectual dimensions.. ${ }^{25}$ One may notice this trend by observing the voluminous documents of the Majlis Tarjih named Tanya Jawab Agama Volume V.

By interpreting tajdi as a form of reform in ritual purification, Muhammadiyah has, in other words, ignored the social aspect of this important term. This is why Ahmad Jainuri argues that Muhammadiyah is incapable of responding to what he calls the actual social issues of our society. This means that Muhammadiyah needs to participate actively in dealing with social problems in a way that would benefit the organisation and open up the intellectual and social horizons of its members. What Jainuri means by social problems are things like corruption, collusion, nepotism, pornography, and selfishness. ${ }^{26}$

The methods and subject-matter of Muhammadiyah's preaching have also come under severe criticism. Its preaching has thus far focused on what is commonly known as 'TBC' (Takhayul, Bid'ah, Churafat: myths, innovation and distortion of original Islamic teachings) as well as other forms of syncretism. These are the contexts that gave birth to liberal discourse within Muhammadiyah, a discourse advocated mostly by its young intellectuals.

\section{Educational Background}

A close look at the educational background of young Muhammadiyah intellectuals makes it clear that these intellectuals have diverse intellectual upbringings. Some of them hold bachelor degrees while others hold Masters and even $\mathrm{PhD}$. They also differ in their fields of specialisation. These differences, moreover, are proven to be vital in fostering different views and attitudes toward Islam and its multi-dimensional teachings.

Those who hold Masters, for example, generally incline toward advocating religious pluralism. Among the advocates of religious pluralism are also those who hold $\mathrm{PhD}$ degrees and have acquired a Pesantren education whose methods and traditions are so

25 Syamsul Anwar, "Fatwa, Purification and Dinamization: A Study of Tarjih Muhammadiyah," Islamic Law and Society, vol. 12, no. 1 (2005): pp. 27-44.

${ }^{26}$ Achmad Jainuri, “Tajdid Melawan Kemunkaran Sosial," Suara Muhammadiyah, no. 10, 93 (16-31 Mei 2008), pp. 32-33. 
humanitarian and flexible that many of its graduates in turn become open-minded and flexible too. Equipped with this religion education, they are able to impart a religious point of view in their writings. In fact, it is not uncommon to find them supporting their arguments by quoting verses from the Qur'aæ or Hadił (the Prophet Muhłmmad's traditions) since they seem to be fluent in quoting Quranic exegetes and experts of $\mathrm{H}\{$ dith.

In terms of themes, the writings of the liberals cover a wide array of subjects. However, it is clear that the dominant theme is related to religious pluralism. Several works by intellectuals from this group show impressive productivity, and it is their scientific publications which tend to boost the spread of their progressive ideas.

Another interesting feature of these advocates of pluralism is the way in which social theories are employed as a means of discourse analysis. A Western-style hermeneutic approach is usually employed as frame of analysis in understanding socio-religious phenomena. A hermeneutic approach is relatively popular among them because it is one of the three pillars of JIMM. ${ }^{27}$ Some works that show the use of a Western hermeneutic approach are those by Zakiyuddin Baidhawy, ${ }^{28}$ Pradana Boy ZTF, ${ }^{29}$ and Moh Shofan. ${ }^{30}$ Besides this hermeneutic approach, the theories of social critics, such as Antonio Gramsci's theory of hegemony, and the theory of empowerment of the marginalized by Paulo Freire, are also employed. Of course, the employment of such social theories adds sharpness to the analysis. The incorporation of social discipline makes the discourse an interconnected study.

The opposing group of young Muhammadiyah intellectuals--those who stand against pluralism--also possess good educational

\footnotetext{
${ }^{27}$ Interpretation of the three pillar of JIMM; hermeneutics, critical social theories, and the new social movement, can be seen in, Marpuji Ali dan M. Ali Masduqi, "Jaringan Intelektual Muda Muhammadiyah: Sebuah Eksperimen Gerakan Ilmu," Profetika, vol. 06, no. 02 (Juli, 2004): pp. 189-190.

28 Zakiyuddin Baidhawy, "Al-Ruju' ila al-Qur'an: Dari Kebebalan Fondasionalisme Menuju Pencerahan Hermeneutis," in Pradana Boy ZTF and M. Hilmi Faiq (eds), Kembali ke al-Qur'an Menafsir Makna Zaman (Malang: UMM Press, 2004), pp. 3-25.

${ }^{29}$ Pradana Boy, "Membangun Relasi Teks-Konteks: Keimanan dan Pencarian Bentuk Masyarakat Ideal," in Ibid., pp. 111-127.

30 Moh. Shofan, "Urgensi Pembacaan Ulang terhadap al-Qur'an: Menakar Kembali Kebenaran Agama," in Ibid., pp. 71-81.
} 
backgrounds. Some of them hold undergraduate degrees, but many have postgraduate and even doctoral degree. They tend to have a strong religious education and are well-versed in traditional Islamic knowledge from their upbringing in the pesantren. Many of them, such as Adian Husaini and Andri Kurniawan, also specialise in Islamic studies and are experts in Arab-Israel studies.

This strong religious educational background helps this group to exert their authority in criticizing secularism, pluralism and, liberalism in Indonesia. The emphasis of their critiques is on the historical and normative aspect of so-called secular ideas in comparison to Islam. In their efforts to reject "secular ideas", they frequently quote Qur'anic verses, $\mathrm{H}\{$ dith, and interpretations of the Qur'a by the 'ulama $\rightarrow$ s well as Islamic jurisprudence. In comparison with their adversaries, this group declines to incorporate social theories, including hermeneutics, in their analysis of socio-religious phenomena.

In addition, the opponents of religious pluralism in general do not publish their works. Adian Husaini, Syamsul Hidayat, and Akhmad Khoirul Fata are the few exception. These three have writen many works for the in national mass media as well as for Journal Islamia. Others rarely write, and if they do, they publish their work in local magazines, especially the Tabligh published by Majlis Tabligh dan Dakwah Khusus (special division for preaching) of Muhammadiyah's central board. This shows that the opponents of pluralism have very limited access to other social groups and have therefore limited chance to spread their ideas. This is quite different from their adversaries, the advocates of pluralism, who are able to utilize the media very well and hence propagate their ideas in an effective manner.

\section{Social Interaction}

One important sociological perspective offered by Peter L. Berger is the fact that unique reality (sui generis) will be found in every individual's point of view. This unique reality can be understood if every person's social background is known. ${ }^{31}$ One variable included as

\footnotetext{
31 Peter L. Berger has offered dialectic formula to understand one's construction of knowledge in sociological perspective. The formulation is externalization, objectivication, and internalization. The dialectic of these phases can happen simultaneously which reflect the two-way relationship between individual and one's social context. Further see, Peter L. Berger, Langit Suci: Agama Sebagai Realitas Sosial, transl. Hartono (Jakarta: LP3ES, 1991), p. 5.
} 
social background is the interaction between individual and other figures within their environment and with society. It is only by understanding a person's education and social interaction background that the variety of each individual's views can be described.

Young Muhammadiyah intellectuals, both those who support and oppose religious pluralism, have a range of interaction experiences with their social surroundings. Generally, those who support pluralism seem to have more interaction with their social community. Furthermore, in their interaction, they do not see social background as a consideration in choosing their dialogue partner. They can enjoy discussion, share processes, and work together with individuals and communities across ethnicity, culture and religion. Some of the young Muhammadiyah intellectuals supporting pluralism also have visited shrines of other religions. Admittedly, visiting churches, temples, and Vihara might seem unusual or anomalous to some Muslims. However, these progressive intellectuals claim the opposite is true. They feel that they gain a great deal of understanding from visiting the shrines of other religions.

Furthermore, the group that supports religious pluralism states that their interaction with other communities across ethnicity, culture and religion is essential in shaping their opinions as well as their attitudes towards the idea of pluralism. Zuly Qodir affirms this stance by stating the benefits of interfaith dialogue activities that he has been participating in for more than five years. Qodir says that he obtained valuable insight from interfaith dialogue, especially in understanding the pluralistic nature of social reality. Qodir admits that interfaith dialogue is risky because it can arouse suspicion among both Muslims and non-Muslims. Among the Muslim community, interfaith dialogue activists are often accused of selling their faith and, additionally, their religious commitment is questioned. Meanwhile, among non-Muslims, these activists may be distrusted and viewed as agents of Islamization. Nevertheless, none of these allegations will stop Qodir's commitment to continuing his activities in interfaith dialogue. He states that interfaith dialogue must be conducted for the purpose of enabling people to understand each other and respect differences. The dialogue 
is not intended to seek out a dialogue partner's weaknesses or to defeat them. ${ }^{32}$

Similarly, Sukidi asserts that his graduate study experiences in Ohio, Athens, USA, have strengthened the pluralistic elements in his theological perspective. Although his postgraduate field was politics and history in Southeast Asia, Sukidi took Hinduism and Buddhism as a minor field of study. Through these subjects he was introduced to the thoughts and views of Mahatma Gandhi who, according to him, is very pluralist. Sukidi also met Farid Esack, who taught Progressive Islam. Sukidi asserts that Farid Esack is a true pluralist since he gained vast experience in coordinating interfaith solidarity to fight against the apartheid regime in South Africa. Farid Esack has shown the world that religious identity is not a barrier to any struggle for the realization of justice, truth and peace. His experience has inspired Sukidi to believe that the true faith is a faith liberating the oppressed. In Sukidi's point of view, the enemy of pluralist Muslims is nothing to do with religious identity but is related to injustice and authoritarian behavior. These two, injustice and authoritarian behavior, can be attached to anyone regardless his or her religious conviction. ${ }^{33}$

Interaction with communities across faith and religion has also been experienced by Ahmad Najib Burhani, Pradana Boy, Zakiyuddin Baidhawy, and Moh Shofan. This can be seen from their active participation in various academic forums involving interfaith prominent figures. Ahmad Najib Burhani, Pradana Boy, and Zakiyuddin Baidhawy are among those who have had interaction with the prominent interfaith figures in many forums in Indonesia and abroad. In addition, Burhani's position as a researcher in Centre for Humanities and Culture Research of Indonesia's Science Institute (PMB-LIPI) has also had a considerable influence in shaping his point of view.

Through many events held by the Center for Culture and Social Change Study at Muhammadiyah University of Surakarta (PSB-PS UMS), Zakiyuddin Baidhawy has also had an opportunity to conduct dialogues and to see at firsthand the art of creativity and interfaith

\footnotetext{
32 Zuly Qodir, "Jalan Spiritualitas Kaum Beriman, Berislam dalam Pluralisme Agama," in Abd. Rohim Ghazali, et. al. (eds), Muhammadiyah Progressif: Manifesto Pemikiran Kaum Muda (Yogyakarta: JIMM dan LESFI, 2007), p. 442.

33 Sukidi, "Menjadi Muslim Pluralis: Pergulatan Mencari Kebenaran dan Tuhan," in Ghazali (ed.), Muhammadiyah Progressif, p. 428.
} 
culture. According to him, PAS or the art of appreciation and education program, held by PSB-PS UMS, along with art of interfaith culture activities, can be a media to develop a pluralist and multicultural religious life. ${ }^{34}$ Shofan has also had interaction with several figures well known as the advocates of pluralism, namely Syafi'i Anwar (born in 1953), Dawam Rahardjo (born in 1942), and Budhy Munawar Rachman.

These proponents of pluralism acknowledge that interfaith dialogue contributed a great deal in shaping their point of view. In this sense, JIL is the primary driving force. According to Qodir, JIL with its liberal discourse, developed since 2001, has gradually grown to become a serious competitor for the "older" discourse. Liberal Muslim communities can be regarded as a new genre in the typology of contemporary Indonesian Islamic thought breaking with the rather stagnant way of thinking of the older generation. ${ }^{35}$ Qodir also actively engages in many academic forums held by the Christian ministers, Catholic priests, and "left wing" groups. He admits that this academic interaction has significantly influenced him. Qodir has also written a paper on the formalization of Islamic law in Indonesia in Taswirul Afkar, a scholarly journal published by the Center for Study and Human Resources Development of NU (Lakpesdam NU).

The interaction between JIMM and JIL cannot necessarily be seen as an indicator that JIMM is influenced by, or similar to, JIL. According to Pradana Boy, even though JIMM was launched in 2003 after the establishment of JIL, they are different in many ways. They do not influence each other, and do not represent each other. ${ }^{36}$ Boy's statement aims to neutralize perceptions stating that JIMM is an extension of JIL and exists to help spread 'the virus of liberalism within Muhammadiyah. ${ }^{37}$ Likewise, Burhani suggests that people often see JIL and JIMM as one or similar due to the 'liberal' label that is attached to both of them and because of the similarity of ideas offered

\footnotetext{
34 Alis, “Seni Mengelola Keragaman,” Kalimatun Sawa', vol. 02, no. 02 (2004), p. 48.

35 Zuly Qodir, Islam Liberal (Yogyakarta: Pustaka Pelajar, 2003), p. 97 and p. 108.

36 Pradana Boy, “JIMM sebuah Teks Multitafsir," in Pradana Boy, et. al. (eds), Era Baru Gerakan Muhammadiyah, (Malang: UMM Press dan al-Maun Institute, 2008), p 49.

${ }^{37}$ See, Fakhrurozi Reno Sutan, "Virus Liberalis di Muhammadiyah," Tabligh, vol. 02, no. 08 (Maret 2004): pp. 14-15.
} 
by these two groups. ${ }^{38}$ Yet Muslim Abdurrahman, a senior Muhammadiyah intellectual, hopes that JIMM can become a different movement from other liberal groups. He adds that perhaps the difference could lie in the three pillars developed by JIMM; hermeneutics, the theory of social critique and new social movement. These three pillars affirm that JIMM does not limit its efforts to the strictly intellectual, but extends them to to incorporate social issues. ${ }^{39}$

Ahmad Najib Burhani and Moeslim Abdurrahman stress that the critical and liberal culture embedded within JIMM is not a final destination. The main purpose of JIMM is a kind of praxis movement, implementing changes such as social assistance, defending the oppressed, raising social awareness and becoming directly involved in society.. JIMM activists acknowledge that their inspiration for such social activism originates from Muhammadiyah which, from the beginning, has implanted Al-Ma un theology, which is similar to the theology of the liberation of the oppressed. The effort to fuse intellectualism and activism is the main factor distinguishing JIMM from other liberal Muslim groups. Here can be seen the ways in which JIMM activists attempt to identify themselves through the process illustrated by Peter L. Berger: externalization, objectification, and internalization. Through this very process they become what they are, they display sui generist characteristics, and appear different from other liberal Muslim groups.

In contrast to the extensive interfaith experience of pluralist activists, it can be said that the opponents of religious pluralism have relatively poor interaction with interfaith communities. Even if there is such an interaction, it generally happens in a forum of dialogue in theology or more precisely in a debate, rather than dialogue. In other words, borrowing from Mukti Ali, such interaction is not e a constructive one and does not cover sectors such as social life, sharing of religious experiences, or praying together. ${ }^{40} \mathrm{~A}$ dialogic

38 Ahmad Najib Burhani, "JIMM: Pemberontakan Anak-anak Muda terhadap Aktivisme, Skripturalisme, dan Orientas Struktural di Muhammadiyah", in http://us.f364.mail.yahoo.com/ym/showletter?msgld=9189_2513878_2199_1839_19 0147 (Accessed: 5 Mei 2007), p. 9.

${ }^{39}$ Moeslim Abdurahman, “Tiga Pilar JIMM,” in Boy, Era Baru, pp. 195-199.

40 A. Mukti Ali, "Ilmu Perbandingan Agama: Dialog, Dakwah, dan Misi," in Burhanuddin Daya and Herman Leonard Beck (eds), Ilmu Perbandingan Agama di Indonesia dan Belanda, (Jakarta: INIS, 1992), pp. 226-231. 
attitude in interfaith relations, according to Diana L. Eck can be a medium to show the openness of adherents of different religions to offer and receive criticism. ${ }^{41}$

The majority of young Muhammadiyah intellectuals who oppose religious pluralism look at interfaith dialogue as a theological term. One of these intellectuals is Masyhud, well known as a Christology expert, and also a student of the popular Christology expert, $\mathrm{KH}$ Abdullah Wasian. Masyhud frequently invites Catholic and Christian priests to engage in theological debate. The dialogue is usually set in a debate style, which results in a situation where one party is a winner and the other is a loser. Most of the time, this kind of dialogue is aimed at defeating the other party, not at sharing information and knowledge about the faith and rituals so deeply that there is a willingness to understand each other. ${ }^{42}$

Opponents of pluralism do engage in social interaction through communication with various organizations; however, this social interaction is principally within their internal Islamic environment. Consequently, the scope of their social interaction is very limited and exclusive. Moreover, their dialogue partners are usually organizations with an 'exclusivist' inclination, such as DDII (Dewan Dakwah Islamiyah Indonesia), KISDI (Komisi Indonesia untuk Solidaritas Dunia Islam), Dewan Masjid, Korp Muballigh, and MUI (Majelis Ulama Indonesia). Consequently, they become exclusive, militant, and tend to be radical.

\section{The Genealogy of Knowledge}

Analysis of the genealogy of knowledge shows that almost all researchers believe in the connection between the views of young Muhammadiyah's intellectuals and the views s of Muhammadiyah's early generation. Interestingly, these young Muhammadiyah activists, both those who agree and those who disagree with religious pluralism, mention Ahmad Dahlan (1868-1923) and Mas Mansur (1896-1946) as important figures who have inspired them how to understand and take a stance on pluralism. Undoubtedly, they see those figures, Ahmad Dahlan and Mas Mansur, from different perspectives.

41 Diana L. Eck, "What is Pluralism," Nieman Reports God in the Newsroom Issues, vol. XLVII, no. 2 (summer, 1992), p. 1.

42 Ali, "Ilmu Perbandingan Agama," p. 211. 
In the view of those who advocate pluralism, Ahmad Dahlan is seen as inclusive, pluralist, open-minded and tolerant towards various religious views. ${ }^{43}$ Ahmad Dahlan's open-minded character can be seen from his wide social network and from his propagation. To give one example, Ahmad Dahlan once joined Budi Utomo, an organization run mostly by the nationalist group. Subsequently, the relationship between Budi Utomo and Muhammadiyah became closer. In fact, when Budi Utomo held its congress in 1917, Ahmad Dahlan's house was one of the venues. The founder of Budi Utomo, Sutomo, was also involved in many Muhammadiyah activities and once held a position as an advisor. At the $26^{\text {th }}$ Muhammadiyah's congress in Surabaya, Sutomo was given a chance to deliver a speech entitled "Penolong Kesengsaraan Umum" or "The helper of social misery".

Ahmad Dahlan's character, very tolerant towards various religious views, is embodied in his teachings. He stated that no single group or ideology deserves the right to claim the truth. Ahmad Dahlan also taught Muhammadiyah leaders, when they are given a chance to speak, to always state as follows: “This is Muhammadiyah's opinion or stance," and discouraged them from statements such as "Muhammadiyah's view is the only and absolute truth which is valid". ${ }^{4}$ The openness of Ahmad Dahlan also can be seen from Muhammadiyah's readiness to invite other Islamic scholars to express their opinions. This showed his positive appreciation of other religious views outside Muhammadiyah.

Meanwhile, Mas Mansur is seen as a Muhammadiyah scholar who paved the path towards the development of religious relativism. In interpreting the basic tenets of Muhammadiyah concerning "Memperluas Pandangan Agama" or "expanding religious view" he states that Islam is actually a simple and easy religion. He gives two reasons for his argument: first, Islamic jurisprudence is adjustable based on people's condition or circumstances. For example, Islam requires people to perform słlas by standing up, sitting, or laying on the bed due to medical conditions. Another example of this flexibility

\footnotetext{
${ }^{43}$ Interview with Zuly Qodir and Moh. Shofan, Malang, 12 February 2008.

44 Cited from Achmad Jainuri, Ideologi Kaum Reformis: Melacak Pandangan Keagamaan Mubammadiyah Periode Awal (Surabaya: LPAM, 2002), p. 117.
} 
is that wudi $>$ ran be substituted by tayammum in some circumstances such as illness or the unavailability of water. 45

Second, Islam does not force Muslims to adhere a particular interpretation of religious texts. By showing that textual characteristics of the Qur'aß and Hadit are multiinterpretable, Mas Mansur states that Islamic teaching allows room for various religious views. This array of religious views is dependant upon the quality of human interpretation. The more knowledgeable a person is in the science of the Qur'a and Hadith, the easier it is for him or her to understand Islamic teaching. Some people who find it difficult to practice Islam must not relate the difficulty to Islam. Rather, the problems lie in his or her understanding of Islam.

To illustrate his point, Mas Mansur provides the example of halal food. According to him, the fact that some people worry too much about buying and selecting meat for consumption is one reason why Islamic teaching sometimes seems hard to observe. Some people are reluctant to eat food before knowing for sure that it is hyla $\mathbf{P}$ Their doubts range from whether the meat comes from a slaughtered animal, to whether the animal was slaughtered with the mention of the name of Allah (basmalab). According to Mas Mansur, this way of life is certainly not a good way of practicing religion. Here, it is clear that difficulties in practicing religion are most of the times sourced from a person's lack of knowledge, or a narrow-minded interpretation of the religion itself.

In contrast to the pluralists, the young Muhammadiyah intellectuals who oppose religious pluralism assert the conservativeness of Ahmad Dahlan and Mas Mansur. Syamsul Hidayat, for example, states that Ahmad Dahlan's motivation in establishing Muhammadiyah was to purify the interpretation and the practice of Islamic teaching. Consistent with this goal, Muhammadiyah also intended to eliminate ignorance among Muslim community. Therefore, Ahmad Dahlan's tried to synergize the purification and the strengthening of Islamic teaching with education and enlightenment programs. Nowadays, according to Syamsul Hidayat, Islamic theology and ritual in general,

${ }^{45}$ Ibid. 
and within Muhammadiyah in particular, face threats from the advocates of secularism, pluralism and liberalism. ${ }^{46}$

Motivated by the will to emulate Ahmad Dahlan's teachings, Syamsul Hidayat rejects pluralism and urges other Muhammadiyah members to clean and purify Muhammadiyah from paganism and liberalism. He also encourages Muhammadiyah members to be consistent in keeping the khittog (basic ideology) of the organization's struggle. This is emphasized because Muhammadiyah nowadays faces the challenge, from liberalism and pluralism, of a relativist view of theology. According to Hidayat, this theory asserts that it is impossible for a person to find the absolute truth in his or her religious practice, and consequently, it is also impossible for him or her to conceive the originality and authenticity of Islamic teaching. ${ }^{47}$

Besides the early generation of Muhammadiyah, supporters of religious pluralism also refer a lot to the thoughts of Syafi'i Ma'arif, Amin Abdullah, Munir Mulkhan, and Moeslim Abdurrahman. For young, progressive, Muhammadiyah intellectuals, these figures are Muhammadiyah's living intellectuals who publicly support and advocate the ideas proposed by JIMM. Their ideas are viewed as a new school of Islamic thought that attempts to understand Islamic teaching with contemporary theories and methodologies. In many aspects, these three Muhammadiyah intellectuals are considered mentors and patrons by the JIMM activists. ${ }^{48}$ In the paramount position is placed Ma'arif, whose open-mindedness has paved the way for progressive thoughts within Muhammadiyah. Another scholar perceived as an inspiration is Dawam Rahardjo. According to Shofan, Rahardjo's views and his determination in continuously promoting a peaceful, tolerant and pluralistic life has made a valuable contribution to the development of intellectual discourse among young Muhammadiyah intellectuals. ${ }^{49}$

\footnotetext{
${ }^{46}$ Syamsul Hidayat, "Sikap Muhammadiyah terhadap Pluralisme Agama," Tabligh, vol. 05, no. 04 (2007), p. 21.

47 Syamsul Hidayat, "Kepemimpinan Istiqomah dalam Muhammadiyah: Bersihkan Muhammadiyah dari Paganisme dan Liberalisme," Suara Mubammadiyah, no. 09, 90 (115 Mei 2005), pp. 30-31.

${ }^{48}$ Burhani, "JIMM: Pemberontakan Anak-anak Muda”, p. 17.

${ }^{49}$ Interview with Moh. Shofan, Jakarta, 6 July 2007.
} 
The most inspiring personality for young Muhammadiyah intellectuals supporting religious pluralism is Ma'arif. Ma'arif steps forward to defend the group whenever its critics attack. When he delivered speech on his inauguration as general leader of Muhammadiyah on 7 July 2005 in Malang, Ma'arif clearly defended young people in the organization who have liberal thoughts. Ma'arif even urged all Muhammadiyah members to not easily get irritated with those progressive members and their liberal ideas. He asserts that as long as they are still committed to and practice Islamic principles such as performing stals (prayer), then there is no need to antagonize them. ${ }^{50}$ This statement was a great relief to those young members of Muhammadiyah who are categorized as liberal. Additionally, Ma'arif on many occasions has also stated that he wants Muhammadiyah to accommodate a variety of schools of thought within Islam

Interestingly, certain scholars outside Muhammadiyah are also regarded as inspirational figures by progressive young activists in Muhammadiyah. They are Madjid and the intellectuals in the Paramadina Institute. Madjid has had a significant influence on shaping their thoughts. ${ }^{51}$ Sukidi, for example, is one of those who perceive Madjid as a very influential figure in constructing his thoughts. He states as follows;

Madjid and the Paramadina have become the seed-bed for my personal theological struggle, in searching for the truth and God. The inclusive view of Madjid, is enriched by Qomaruddin Hidayat, Budhy Munawar Rahman and other associates in the Paramadina, has influenced my desire to emulate and enrichen the theological mainstream of young intellectuals. From this point, the first seed of my theology flourished. I begin to realize that inclusiveness, truth, and salvation have spread outside (Islam) to other religious traditions. Truth and salvation are not monopolized by one particular religion, but have become the big umbrella of all religions. I then fell in love with this model of inclusive theology, which affirmed me to acknowledge the truth and the salvation outside Islam. ${ }^{52}$

\footnotetext{
${ }^{50}$ Burhani, "JIMM: Pemberontakan Anak-anak Muda", p. 18.

51 Zuly Qodir, Pembaharuan Pemikiran Islam: Wacana dan Aksi Islam Indonesia (Yogyakarta: Pustaka Pelajar, 2006), p. 67.

52 Sukidi, Menjadi Muslim, p. 415.
} 
Sukidi's statement shows that Madjid has succeed in opening the way for the seed-bed and the development of inclusive theology in Indonesia. However, Sukidi does not want to be content just being the follower of this so-called inclusive theology. More than that, Sukidi wants to go beyond the level of inclusive Muslim to become a pluralist Muslim. This step is intended to ensure that inclusive theology does not end at the level of mere discourse but is manifested in daily behavior. According to Sukidi, pluralist theology is not only adaptive to religious pluralism but also is compatible with social plurality. ${ }^{53}$ This acknowledgement shows the interconnection between his views and contemporary thought outside Muhammadiyah. Actually, Sukidi is not the only Muhammadiyah intellectual to interact with intellectuals outside Muhammadiyah; in fact, almost all young progressive Muhammadiyah intellectuals do so. This means that exchange of ideas between young Muhammadiyah intellectuals and the progressive intellectuals outside the organization has had a significant influence on their views.

Turning once again to the opponents of pluralism within Muhammadiyah, most of them mention Yunahar Ilyas, Muhammad Muqaddas, and Mushtafa Kamal Pasha as their sources of inspiration. The conservativeness and careful attitude of these figures have had a significant influence on those who oppose pluralism. Ilyas, for example, questions JIMM's existence and its ideas and considers it a violation of the organization rules. ${ }^{54}$ Muqaddas has a very careful and cautious attitude towards the phenomenon of liberal Islam. ${ }^{55}$ Pasha, an intellectual educated in Madrasah Muallimin Muhammadiyah in Jogjakarta, is known to be very eloquent in campaigning against many ideas of liberal Islam. He rejects pluralism outright and looks at it simply as form of Christian culture. He also criticizes western-style hermeneutic methods used by the supporters of liberal Islam in interpreting the Qur'an because this method is regarded as unusual and imported from Christianity. This implies that followers of liberal Islam have simply adopted a Christian theology, which is then crammed into

\footnotetext{
53 Sukidi, Teologi Inklusif Cak Nur (Jakarta: Kompas, 2001), pp. xxxi-xliii.

54 Yunahar Ilyas, "JIMM Menyalahi Organisasi," Tabligh, vol. 02, no. 08 (Maret 2004), p. 20.

55 Muhammad Muqaddas, "Saya Berhati-hati Menyikapi Islam Liberal," Tabligh, vol. 02, no. 08 (Maret 2004), p. 20.
} 
an Islamic framework. Therefore, he states, liberal Islam's ideas on religious pluralism and western-style hermeneutics will eventually poison the young generation of Muhammadiyah. ${ }^{56}$ According to Pasha, the founders of Muhammadiyah resolutely stated that Islam is the only religion of truth, salvation, and perfection. ${ }^{57}$ For Yunahar Ilyas pluralism means the fact that there are many religions. This is religious plurality, not religious pluralism. Discourse on religious plurality was actually taught by the prophet Muh łmmad in the Madiæah Charter. In the Madinah Charter, the prophet treated all citizens equally regardless of their ethnicity and religion, so that the rights of a Jew were equal to those of a Muslim. Pluralism, defined as plurality, is also adhered to by young Muhammadiyah intellectuals who oppose pluralism. In their view, religious plurality is an undeniable fact that must be acknowledged. Muslims are obliged to have good relations with communities across religious boundaries. However, this teaching to be tolerant does not imply an obligation to acknowledge the truth of other religions. In their opinion, Islam, as the final religion, has the absolute truth. As a result, the truth of Islam is exclusive. ${ }^{58}$

Outside these three scholars, Hamka (1908-1984) seems to be very influential in shaping young exclusivist intellectuals' views. According to Fata, Hamka proposed a basic understanding of monotheistic principle and its application, such as theological purity, ritual matters, and how to perform Islam and be a good Muslim in accordance with the Qur'aæand the Sunnah. Fata also mentions Adian Husaini as the pre-eminent critic of liberal Islam. According to Fata, Husaini's efforts in criticizing liberal Islam have inspired him to adopt a clear position in opposition to the phenomenon of liberal Islam. In addition, as Fata notes, Hamka and Husaini are both recognized as resolute persons as well as prolific writers. ${ }^{59}$

\footnotetext{
${ }^{56}$ Musthafa Kamal Pasha, "Islam Liberal Meracuni Kalangan Muda," Tabligh, vol. 02, no. 08 (Maret 2004), p. 21.

57 Boy, Era Baru, p. 187.

58 Yunahar Ilyas, "Muhammadiyah tidak akan Jadi Organisasi Liberalis," Tabligh, vol. 03, no. 09 (Juli 2005), pp. 36-37. See Yunahar Ilyas, "Aplikasi Tajdid dalam Pengamalan Agama," in Mifedwil Jandra and M. Safar Nasir (eds), Tajdid Mubammadiyah untuk Pencerahan Peradaban (Yogyakarta: MTPPI dan UAD Press, 2005), pp. 50-51.
}

${ }^{59}$ Interview with Ahmad Khoirul Fata, Surabaya, 12 April 2008. 


\section{Conclusion}

According to Diana L. Eck, the definition and understanding of pluralism has evolved rapidly. ${ }^{60}$ Pluralism does not only mean relativism as understood in philosophy and theology. Philosophical and theological perspectives about pluralism give rise to the absolutistic claim of the truth of particular religion. In this way, pluralism frequently causes controversy. The evolving definition of pluralism shows that this idea has been interpreted from various perspectives, socially, politically, and anthropologically. With this understanding, there should be no more psychological barrier to develop discourse on pluralism. Understanding pluralism from many perspectives will encourage the realization of pluralism values in this plural society. A person does not have to understand pluralism from philosophical and theological perspectives because that may not encourage one to understand plurality in order to construct a tolerant attitude.

Conceptually, pluralism can be understood both in positive and negative senses. In the positive sense, pluralism means tolerance, optimism, and sincerity. Positive pluralism helps create an inclusive and pluralist society. On the other hand, negative pluralism refers to an inward-looking, close-minded discourse that tends to relativism. In this form of pluralism there is no commitment from each individual and group to be actively involved in dialogue. Indeed, such an attitude should be a concern for all religions. If interfaith dialogue is conducted, then most of the time this dialogue is nothing more than a theological debate that only fosters exclusive attitudes and militancy.

By using sociology as a perspective in understanding people's thought, this research suggests that external factors (ideology, politics, economy and intellectual debate) and social backgrounds (education, social interaction, and knowledge genealogy) have contributed to the shaping of an individual's thoughts. This, once again, implies that knowledge is a product of social condition. Diversity of social background will generate diversity of knowledge and finally shape the uniqueness of one's thoughts (sui generis). By understanding this diversity of social background, differences, including those of opinions, should be viewed as an inevitable facts and consequently demand tolerance and respect from each other. This indicates that a

${ }^{60}$ Eck, What is Pluralism, pp. 1-3. 
sociological perspective, as stated by Berger, may be very useful as an approach in socio-religion researches. Also asserted by Manheim, human knowledge cannot be separated from subjectivity. Knowledge and existence are two inseparable things. ${ }^{61}$ This means that all people will understand and see a reality from their own perspective. Here, the perspective means the ways in which a person sees an object, what he or she knows about that object, and how that person interprets that object in his mind. []

\section{Bibliography}

\section{Books and Articles}

Abdurrahman, Moeslim. "Tiga Pilar JIMM." in Pradana Boy, et. al. (ed). Era Baru Gerakan Muhammadiyah. Malang: UMM Press dan al-Maun Institute (2008): pp. 195-199.

Ali, A. Mukti. "Ilmu Perbandingan Agama: Dialog, Dakwah, dan Misi." in Burhanuddin Daya and Herman Leonard Beck (eds). Ilmu Perbandingan Agama di Indonesia dan Belanda. Jakarta: INIS, (1992): pp. 226-231.

Ali, Marpuji and M. Ali Masduqi. "Jaringan Intelektual Muda Muhammadiyah; Sebuah Eksperimen Gerakan Ilmu." Profetika. Vol. 06, no. 02 (Juli, 2004): pp. 189-200.

Alis. "Seni Mengelola Keragaman." Kalimatun Sawa'. Vol. 02, no. 02 (2004): p. 48.

Anonym. "Laysa Minna: Mereka Bukan Golongan Kami (Jejak Liberalisme, Pluralisme, Inklusivisme di Muhammadiyah)." Swaramuslim.net. 26 June 2004.

Anwar, Syamsul. "Fatwa, Purification and Dinamization: A Study of Tarjih Muhammadiyah." Islamic Law and Society. Vol. 12, no. 1 (2005): pp. 27-44.

Arifin, Syamsul. "Jangan Biarkan Keberagaman Dicederai." Jawa Pos (3 Juni 2008): p. 4.

Azra, Azyumardi. "Muhammadiyah; A Preliminary Study." Studia Islamika. Vol. 1, no. 2 (1994): pp. 187-200.

${ }^{61}$ Karl Mannheim, Ideologi dan Utopia: Menyingkap Kaitan Pemikiran dan Politik, transl. F. Budi Hardiman (Yogyakarta: Kanisius, 1991), pp. 295-296. 
Bahtiar, Asep Purnama and Nurwanto. "Wacana dan Agenda Reformasi Muhammadiyah." in Imron Nasri (ed). Pluralisme dan Liberalisme: Pergolakan Pemikiran Anak Muda Mubammadiyah. Yogyakarta: Citra Karsa Mandiri, 2005.

Baidhawy, Zakiyuddin. "Al-Ruju' ila al-Qur'an: Dari Kebebalan Fondasionalisme Menuju Pencerahan Hermeneutis." in Pradana Boy and M. Hilmi Faiq (eds). Kembali ke al-Qur'an Menafsir Makna Zaman. Malang: UMM Press,( 2004): pp. 3-25.

Berger, Peter L and Thomas Luckman. The Social Construction of Reality: A Treatise in the Sociology of Knowledge. England-USA: Penguin Books, 1991.

Berger, Peter L. Langit Suci: Agama Sebagai Realitas Sosial. transl. Hartono. Jakarta: LP3ES, 1991.

Boy, Pradana, et. al. (eds). Era Baru Gerakan Muhammadiyah. Malang: UMM Press dan al-Maun Institute, 2008.

Boy, Pradana. "Membangun Relasi Teks-Konteks: Keimanan dan Pencarian Bentuk Masyarakat Ideal." in Pradana Boy and M. Hilmi Faiq (eds). Kembali ke al-Qur'an Menafsir Makna Zaman. Malang: UMM Press (2004): pp. 111-127.

Burhani, Ahmad Najib. "JIMM; Pemberontakan Anak-anak Muda terhadap Aktivisme, Skripturalisme, dan Orientasi Struktural di Muhammadiyah." in http://us.f364.mail.yahoo.com/ym/showletter?msgld=9189_2513878_2199_1839_190147 (5 Mei 2007).

Djamil, Fathurrahman. "The Muhammadiyah and the Theory of Maqasid al-Syariah." Studia Islamika, vol. 2, no. 1 (1995): pp. 53-68.

Eck, Diana L. "What is Pluralism." Nieman Reports God in the Newsroom Issues. Vol. XLVII, no. 2 (summer, 1992).

Federspiel, Howard M. "Muhammadiyah Sebagai Gerakan Islam Ortodoks." in M. Din Syamsuddin (ed.). Muhammadiyah Kini dan Esok. Jakarta: Pustaka Panjimas (1990): pp. 81-121.

Gaus AF, Ahmad. "Islam Progresif: Wacana Pasca Arus Utama (Peta Pemikiran dan Gerakan Islam di Indonesia)." Tashwirul Afkar. $22^{\text {th }}$ edition (2007).

Hidayat, Syamsul. "Kepemimpinan Istiqomah dalam Muhammadiyah; Bersihkan Muhammadiyah dari Paganisme dan Liberalisme." Suara Mubammadiyah. No. 09, 90 (1-15 Mei 2005): pp. 30-31. 
Biyanto

Hidayat, Syamsul. "Sikap Muhammadiyah terhadap Pluralisme Agama." Tabligh. Vol. 05, no. 04 (2007): pp. 21-22.

Husaini, Adian and Nu'im Hidayat, Islam Liberal: Sejarah, Konsepsi, Penyimpangan, dan Jawabannya. Jakarta: Gema Insani Press, 2002.

Husaini, Adian. Islam Liberal, Pluralisme Agama dan Diabolisme Intelektual. Surabaya: Risalah Gusti, 2005.

-. Liberalisasi Islam di Indonesia: Fakta dan Data. Jakarta: Dewan Dakwah Islamiyah Indonesia, 2007.

---------. Pluralisme Agama: Fatwa MUI yang Tegas dan Tidak Kontroversial. Jakarta: Pustaka al-Kautsar, 2005.

Ilyas, Yunahar. "Aplikasi Tajdid dalam Pengamalan Agama." in Mifedwil Jandra and M. Safar Nasir (eds). Tajdid Muhammadiyah untuk Pencerahan Peradaban. Yogyakarta: MTPPI dan UAD Press (2005): pp. 50-59.

-. "JIMM Menyalahi Organisasi." Tabligh. Vol. 02, no. 08 (Maret 2004).

--------. "Muhammadiyah tidak akan Jadi Organisasi Liberalis." Tabligh. Vol. 03, no. 09 (Juli 2005): pp. 36-37.

--------. "Pluralisme Agama dalam Perspektif Islam." in Syamsul Hidayat and Sudarno Shobron (eds). Pemikiran Mubammadiyah: Respon terhadap Liberalisasi Islam. Surakarta: Muhammadiyah University Press, 2005.

Jainuri, Achmad. "Tajdid Melawan Kemunkaran Sosial." Suara Muhammadiyah. No. 10, 93 (16-31 Mei 2008): pp. 32-33.

---------. Ideologi Kaum Reformis: Melacak Pandangan Keagamaan Muhammadiyah Periode Awal. Surabaya: LPAM, 2002.

Karim, M. Rusli (ed.). Muhammadiyah dalam Kritik dan Komentar. Jakarta: Rajawali Press, 1986.

Kurzman, Charles (ed.). Wacana Islam Liberal: Pemikiran Islam Kontemporer tentang Isu-isu Global. transl. Bahrul Ulum. Jakarta: Paramadina, 2003.

Madjid, Nurcholish. Islam Kemodernan dan Keindonesiaan. Bandung: Mizan, 1992.

Mannheim, Karl. Ideologi dan Utopia: Menyingkap Kaitan Pemikiran dan Politik. transl. F. Budi Hardiman. Yogyakarta: Kanisius, 1991. 
McCarthy, E. Doyle. Knowledge as Culture: The Sociology of Knowledge. New York: Routledge, 1996.

Muqaddas, Muhammad. "Saya Berhati-hati Menyikapi Islam Liberal." Tabligh. Vol. 02, no. 08 (Maret 2004): p. 20.

Nakamura, Mitsuo. "The Crescent Arises Over the Banyan Tree: A Study of Muhammadiyah in A Central Java." Unpublished PhD Thesis, Cornel University, 1976.

Pasha, Musthafa Kamal. "Wacana Pluralisme dan Liberalisasi Agama: Keresahan Warga Muhammadiyah." in Syamsul Hidayat dan Sudarno Shobron (eds). Pemikiran Muhammadiyah: Respon terhadap Liberalisasi Islam. Surakarta: Muhammadiyah University Press, (2005): pp. 339-357.

--------. "Islam Liberal Meracuni Kalangan Muda." Tabligh. Vol. 02, no. 08 (Maret 2004): p. 21.

Pimpinan Pusat Muhammadiyah. "Keputusan Muktamar ke-45 tentang Program Muhammadiyah 2005-2010." Berita Resmi Muhammadiyah, no. 01 (September 2005)

Qodir, Zuly. "Jalan Spiritualitas Kaum Beriman, Berislam dalam Pluralisme Agama." in Abd. Rohim Ghazali, et al (eds.). Muhammadiyah Progressif: Manifesto Pemikiran Kaum Muda. Yogyakarta: JIMM and LESFI, 2007.

. "Muhammadiyah dan Pluralisme Agama." in Imron Nasri (ed.). Pluralisme dan Liberalisme: Pergolakan Pemikiran Anak Muda Muhammadiyah. Yogyakarta: Citra Karsa Mandiri, (2005): pp. 8793.

-. Islam Liberal. Yogyakarta: Pustaka Pelajar, 2003.

---------. Pembaharuan Pemikiran Islam: Wacana dan Aksi Islam Indonesia. Yogyakarta: Pustaka Pelajar, 2006.

Shofan, Moh. "Urgensi Pembacaan Ulang terhadap al-Qur'an: Menakar Kembali Kebenaran Agama." in Pradana Boy and M. Hilmi Faiq (eds). Kembali ke al-Qur'an Menafsir Makna Zaman. Malang: UMM Press (2004): pp. 71-81.

Sukidi. "Menjadi Muslim Pluralis; Pergulatan Mencari Kebenaran dan Tuhan." in Abd. Rohim Ghazali, et. al. (eds). Muhammadiyah Progressif: Manifesto Pemikiran Kaum Muda. Yogyakarta: JIMM and LESFI, 2007. 
Biyanto

Sukidi. Teologi Inklusif Cak Nur. Jakarta: Kompas, 2001.

Sutan, Fakhrurazi Reno. "Virus Liberal di Muhammadiyah." Tabligh. Vol. 02, no. 08 (Maret 2004): pp. 14-15.

Yatim, Usman and Almisar Hamid (eds.). Mubammadiyah dalam Sorotan. Jakarta: Bina Rena Pariwara, 1993.

\section{Interviews}

Fata, Ahmad Khoirul. Surabaya, 12 April 2008.

Ilyas, Yunahar. Probolinggo, 20 January 2008.

Qodir, Zuly. Malang, 12 February 2008.

Shofan, Moh. Malang, 12 February 2008.

---------. Jakarta, 6 Juli 2007.

Sutan, Fakhrurazi Reno. Jakarta, 29 August 2007. 